\title{
Gambaran histopatologik hati tikus wistar (Rattus norveginus) yang diinduksi monosodium glutamate (msg) dan diberikan sari air bawang daun (Allium fistulosum $L$.)
}

\author{
${ }^{1}$ Ni Nyoman G. Setiani \\ ${ }^{2}$ Lily Loho \\ ${ }^{2}$ Poppy Lintong
}

\author{
${ }^{1}$ Kandidat Skripsi Fakultas Kedokteran Universitas Sam Ratulangi Manado \\ ${ }^{2}$ Bagian Patologi Anatomi Fakultas Kedokteran Universitas Sam Ratulangi Manado \\ Email: githa.setiani@yahoo.com
}

\begin{abstract}
Monosodium glutamate (MSG) has been consumed around the world as a food additive in the form of L-glutamic acid. The liver has glutamate receptors, hence its susceptibility to damage due to oxidative stress from consuming excessive MSG. Leek contain antioxidants such as flavonoid, which has potent hepatoprotective properties under certain liver conditions, for the example, oxidative stress, liver fibrosis, and fatty liver. This study aims to see the liver histopathologic findings of wistar rats (Ratus norvegicus) that has been induced by MSG and was given leek juice (Allium fistulosum L.). This was an experimental laboratory study, with 20 wistar rats as subjects. In this study, 173,6 mg per gram body of monosodium glutamate and 20 gram per kilogram body weight of leek juice are administered orally each day. Group A is the negative control group. Group B is given MSG for 14 days. Group C are given MSG for 14 days and were stopped for 5 days. Group $\mathrm{D}$ are given MSG for 14 days and were given leek juice. Group A shows normal liver histopathologic features. Group B shows liver cells damage in the form of inflammation and fatty cells. Group $\mathrm{C}$ shows regeneration of liver cells but a little bit of inflammation and fatty cells were still found, while in group D there is a wide regeneration of liver cells and there was barely any inflammation and fatty cells. Conclusion: Microscopic features of wistar rat liver after administration of monosodium glutamate for 14 day showed inflammation and fatty cells and then the administration of leek juice for 5 days after MSG administration oon wistar rat showed a wide regeneration of liver cells compared to no administration of leek juice.
\end{abstract}

Keywords: monosodium glutamate, leek, liver.

\begin{abstract}
Abstrak: Monosodium glutamate (MSG) telah dikonsumsi di seluruh dunia sebagai penambah rasa makanan dalam bentuk L-glutamic acid (asam glutamat). Hati memiliki resptor terhadap glutamate sehingga rentan mengalami kerusakan akibat stress oksidatif dari konsumsi MSG yang berlebihan. Bawang daun mengandung antioksidan seperti senyawa flavonoid yang memiliki aktivitas hepatoprotektif ampuh pada berbagai kondisi hati seperti strees oksidatif, fibrosis hati, dan perlemakan hati. Penelitian ini bertujuan untuk melihat gambaran histopatologik hati tikus wistar (Rattus norvegicus) yang diinduksi MSG dan diberikan sari air bawang daun (Allium fistulosum L.) Jenis penelitian ini eksperimental laboratorik. Subjek penelitian 20 ekor tikus wistar. Pada penelitian ini digunakan monosodium glutamate $173,6 \mathrm{mg} / \mathrm{gBB} / \mathrm{hari}$ dan sari air bawang daun $20 \mathrm{~g} / \mathrm{kgBB} / \mathrm{hari}$ yang diberikan secara oral. Kelompok A (kontrol negatif). Kelompok B diberikan MSG selama 14 hari. Kelompok C diberikan MSG selama 14 hari dan dihentikan selama 5 hari. Kelompok D diberikan MSG selama 14 hari dan diberikan sari air bawang daun. Kelompok A memperlihatkan gambaran histopatologik sel hati normal. Kelompok B memperlihatkan hepatitis dan perlemakan sel hati (steatosis). Kelompok $\mathrm{C}$ memperlihatkan sel hati
\end{abstract}


regenerasi namun masih terdapat sedikit sel radang dan perlemakan hati sedangkan pada kelompok D tampak sel hati regenerasi yang luas dan hampir tidak ditemukan peradangan dan perlemakan. Simpulan: Gambaran mikroskopik hati tikus wistar setelah pemberian monosodium glutamate selama 14 hari menunjukkan peradangan (hepatitis) dan perlemakan (steatosis mikrovesikular) kemudian pemberian sari air bawang daun selama 5 hari pasca pemberian MSG pada tikus wistar menunjukkan adanya regenerasi sel hati yang lebih luas dibandingkan dengan tanpa pemberian sari air bawang daun.

Kata kunci: monosodium glutamate, bawang daun, hati.

Monosodium glutamate (MSG) telah dikonsumsi secara luas di seluruh dunia sebagai penambah rasa makanan dalam bentuk L-glutamic acid (asam glutamat). Monosodium glutamate yang terdiri atas glutamat $78,2 \%$, natrium $12,2 \%$, dan air $9,6 \%$, biasa digunakan sebagai bahan penyedap masakan dengan jumlah bervariasi. ${ }^{1} \quad$ Konsumsi rata-rata monosodium glutamate di Indonesia berdasarkan hasil survei tahun 2000 adalah sebanyak 0,6 g/hari, ${ }^{1,2}$ namun dilaporkan penggunaan monosodium glutamate 0,8 $10,35 \mathrm{~g}$ per porsi bakso dengan rata-rata 4,79 g per porsi. ${ }^{1,2}$ Batas aman konsumsi monosodium glutamate per hari adalah $120 \mathrm{mg} / \mathrm{kg}$ BB, atau sekitar $6,0-8,4 \mathrm{~g}$ per hari dan tidak boleh diberikan dalam dosis tinggi sekaligus. ${ }^{1,3}$

Beberapa penelitian melaporkan kerusakan berbagai organ akibat pajanan monosodium glutamate berlebihan, diantaranya adalah hati. ${ }^{4-6}$ Hati adalah organ yang mempunyai fungsi sangat penting dan kompleks terutama dalam metabolisme lemak, penyimpanan glikogen, pertahanan tubuh, perombakan sel darah merah tua, detoksifikasi zat sisa tubuh, hormon, obat dan senyawa asing lain. ${ }^{6}$ Hati memiliki reseptor terhadap glutamate sehingga rentan mengalami kerusakan akibat stress oksidatif dari konsumsi monosodium glutamate yang berlebihan. ${ }^{1}$ Pada penelitian sebelumnya oleh Eweka AO (2011), tikus yang diberi perlakuan monosodium glutamate mengalami peningkatan kadar transaminase serum, sintesis empedu, lipid peroksidase, serta perubahan morfologi jaringan hati yang ditandai dengan gangguan arsitektur hati, vakuolisasi, degenerasi ,dan atrofi sel hati. $^{7}$

Di Indonesia banyak tanaman herbal yang mempunyai kandungan antioksidan. Bawang daun telah diketahui potensinya sebagai salah satu sumber antioksidan alami. ${ }^{8,9}$ Sebagai antioksidan, bawang daun mengandung beberapa komponen antioksidan seperti senyawa fenolik, flavonoid, karotenoid, dan vitamin C. ${ }^{9,10}$ Setiap bagian dari bawang daun memiliki kandungan antioksidan yang berbeda. Bagian daun dari bawang daun memiliki aktivitas antioksidan yang tergolong tinggi dan merupakan bagian yang sering dikonsumsi. ${ }^{9} \quad$ Bawang daun memiliki aktivitas hepatoprotektif ampuh dan efek yang berbeda pada berbagai kondisi hati seperti stress oksidatif, fibrosis hati, dan perlemakan hati. ${ }^{11}$

Berdasarkan hal-hal tersebut di atas, maka penulis tertarik melakukan sebuah penelitian eksperimental untuk melihat bagaimana gambaran histopatologik hati tikus wistar (Rattus norvegicus) yang diinduksi Monosodium Glutamate (MSG) dan diberikan sari air bawang daun (Allium fistulosum L.).

\section{METODE PENELITIAN}

Jenis penelitian ini eksperimental laboratorik yang dilakukan pada bulan September sampai Desember 2016 di Laboratorium Patologi Anatomi fakultas Kedokteran Univesitas Sam Ratulangi Manado. Subjek penelitian ialah 24 ekor tikus wistar spesies Rattus norvegicus jantan dengan berat rata-rata 150-200g. Monosodium glutamate (MSG) yang digunakan ialah dengan dosis $173,6 \mathrm{mg} / \mathrm{gBB} / \mathrm{hari}$ yang dilarutkan menggunakan $2 \mathrm{ml}$ aquades. Sari air 
bawang daun yang digunakan ialah dengan dosis $20 \mathrm{~g} / \mathrm{kgBB} /$ hari. Keduanya diberikan secara oral menggunakan sonde lambung khusus untuk tikus.

Subjek penelitian dibagi menjadi 4 kelomok, yaitu satu kelompok negatif dan tiga kelompok perlakuan. Kelompok A (kontrol negatif) tidak diberikan perlakuan selama 14 hari. Kelompok B diberikan MSG 173,6 mg/gBB/hari selama 14 hari. Kelompok C diberikan MSG 173,6 $\mathrm{mg} / \mathrm{gBB} / \mathrm{hari}$ selama 14 hari kemudian dihentikan pemberian selama 5 hari. Kelompok D diberikan MSG $173,6 \mathrm{mg} / \mathrm{gBB} / \mathrm{hari}$ selama 14 hari kemudian diberikan sari air bawang daun selama 5 hari. Terminasi hewan uji dilakukan pada hari ke-15 dan 20 untuk mengambil organ hati. Organ hati diproses untuk pembuatan preparat histopatologik dan diamati dengan mikroskop cahaya.

\section{HASIL PENELITIAN}

\section{Kelompok A (kontrol negatif)}

Kelompok A adalah kelompok tikus yang tidak diberi perlakuan dan terminasi dilakukan pada hari ke-20. Gambaran mikroskopik hati tikus wistar pada kelompok ini menunjukkan struktur lobulus hati normal dan tidak ditemukan adanya kelainan. Lobulus hati berbentuk heksagonal dan pada bagian tengah terdapat vena sentralis yang dikelilingi selsel hati yang tersusun radier. Sel hati berbentuk polygonal, inti ditengah, sitoplasma luas dan homogen. (Gambar 1 A dan B).

\section{Kelompok B (Perlakuan 1)}

Kelompok B adalah kelompok tikus wistar yang diberi perlakuan monosodium glutamate $173,6 \mathrm{mg} / \mathrm{gBB} / \mathrm{hari}$ selama 14 hari. Terminasi tikus dilakukan pada hari ke-15. Pada kelompok ini tampak adanya sel radang dan perlemakan hati mikrovesikular. Tampak pula eritrosit di sinusoid (Gambar 2A dan B).

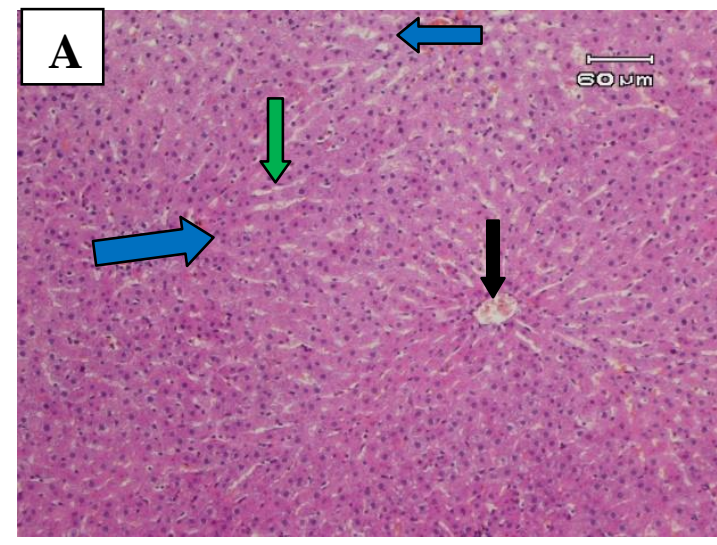

Gambar 1A. Gambaran mikroskopik hati tikus wistar kelompok A (kontrol negatif). Tampak gambaran hati normal dengan vena sentralis (panah hitam), sel-sel hati (panah biru) dan sinusoid (panah hijau) dengan pembesaran 10x.

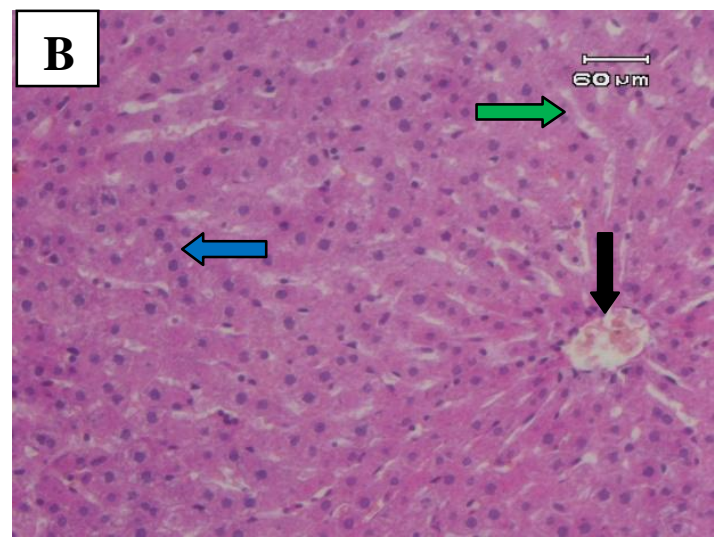

Gambar 1B. Gambaran mikroskopik hati tikus wistar kelompok A (kontrol negatif). Tampak gambaran hati normal dengan vena sentralis (panah hitam), sel-sel hati (panah biru) dan sinusoid (panah hijau) dengan pembesaran 20x

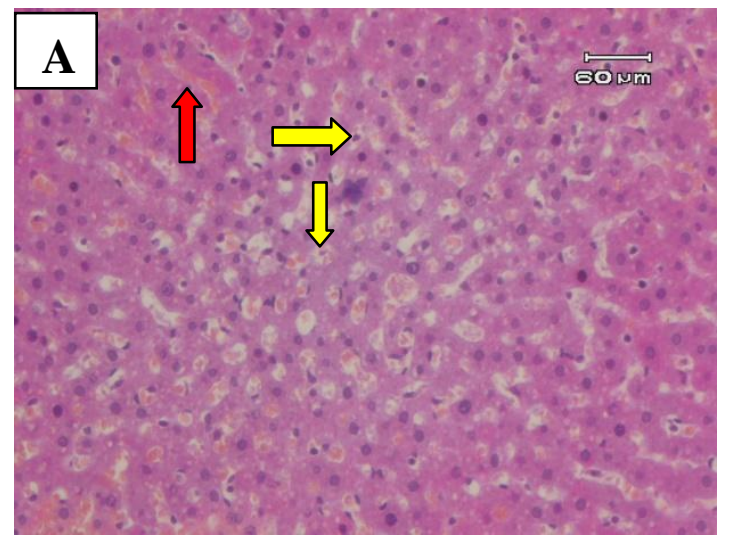

Gambar 2A. Gambaran mikroskopik hati tikus kelompok B (perlakuan 1). Tampak gambaran hati tidak normal dengan adanya perlemakan hati mikrovesikular (panah kuning) dan sinusoid berisi eritrosit (panah merah) dengan pembesaran 20x. 


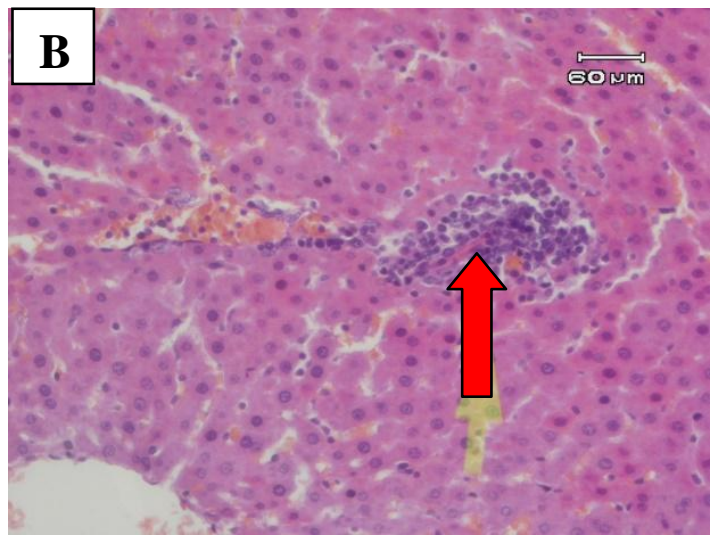

Gambar 2B. Gambaran mikroskopik hati tikus kelompok B (perlakuan 1). Tampak gambaran hati tidak normal dengan adanya sel radang (panah merah). Pembesaran 20x

\section{Kelompok C (Perlakuan 2)}

Kelompok $\mathrm{C}$ adalah kelompok tikus wistar yang diberi monosodium glutamate $173,6 \mathrm{mg} / \mathrm{gBB} / \mathrm{hari}$ selama 14 hari kemudian dihentikan pemberian selama 5 hari. Terminasi tikus dilakukan pada hari ke-20. Pada kelompok ini tampak masih ada sedikit sel radang dan perlemakan mikrovesikular serta adanya beberapa sel hati yang beregenerasi ditandai oleh, inti besar, beberapa sel berinti dua dan bewarna homogen merah muda (Gambar 3A dan B).

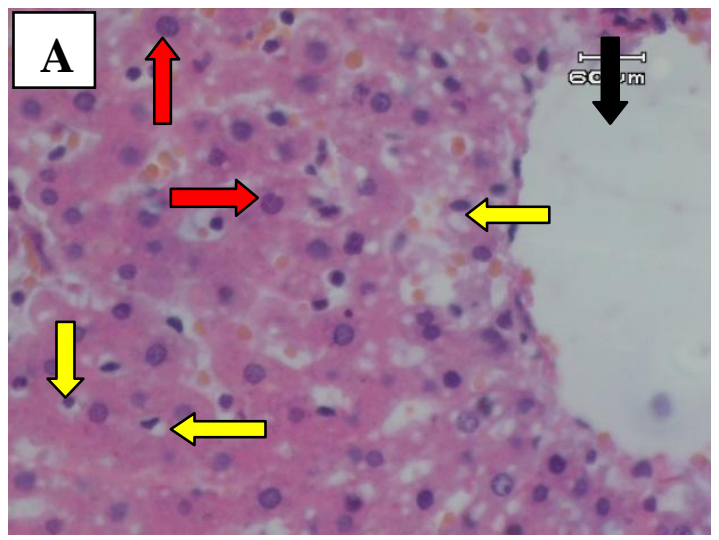

Gambar 3A. Gambaran mikroskopik hati tikus kelompok C (perlakuan 2). Tampak adanya gambaran sel hati yang beregenerasi dengan inti sel yang besar (panah merah), vena sentralis (panah hitam), serta masih ada perlemakan mikrovesikular (panah kuning) Pembesaran 40x.

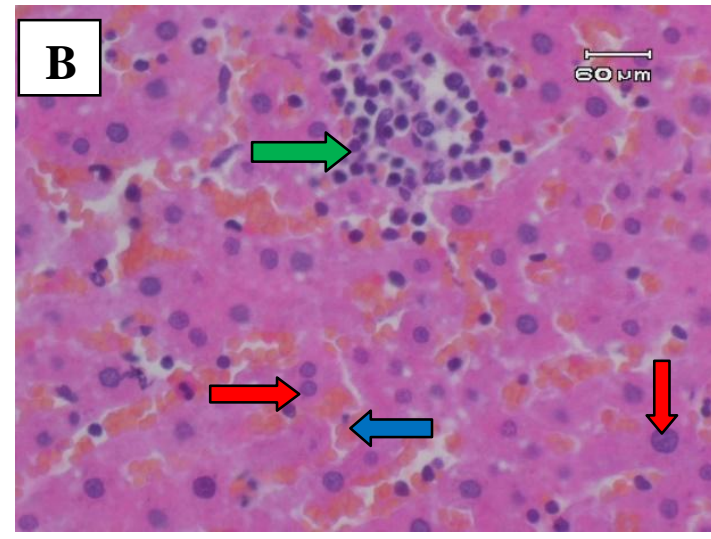

Gambar 3B. Gambaran mikroskopik hati tikus kelompok C (perlakuan 2).) Tampak masih ada sel radang (panah hijau) adanya sel hati yang regenerasi (panah merah) dan sinusoid berisi eritrosit (panah biru). Pembesaran 40x.

\section{Kelompok D (Perlakuan 2)}

Kelompok D adalah kelompok tikus wistar yang diberi monosodium glutamate $173,6 \mathrm{mg} / \mathrm{gBB} / \mathrm{hari}$ selama 14 hari kemudian diberikan sari air bawang daun 20g/kgBB/hari selama 5 hari. Terminasi tikus dilakukan pada hari ke-20. Pada kelompok ini tampak adanya sel hati yang regenerasi, memiliki inti besar, berwarna homogen merah muda dan sel berinti 2. Sel radang dan perlemakan hati mikrovesikular masih ditemukan tetapi hanya sebagian (Gambar 12 \& 13).

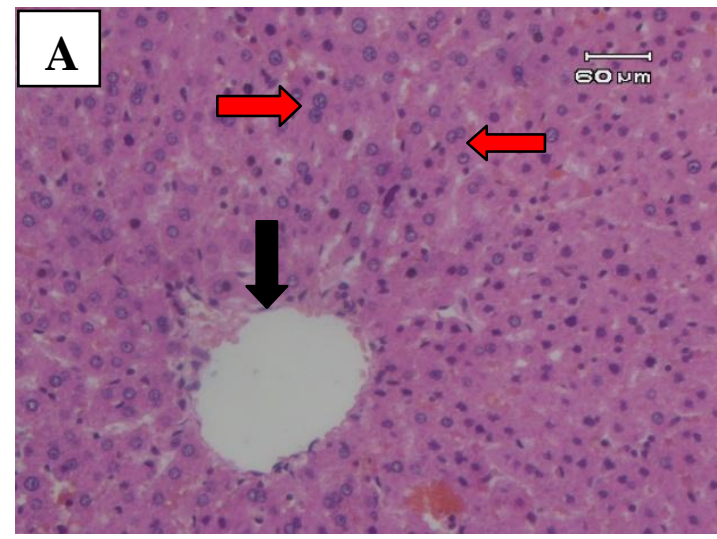

Gambar 4A. Gambaran mikroskopik hati tikus kelompok D (perlakuan 3). Tampak adanya gambaran sel hati yang mengalami regenerasi pada sebagian jaringan (panah merah), vena sentralis (panah hitam). Pembesaran 10x. 


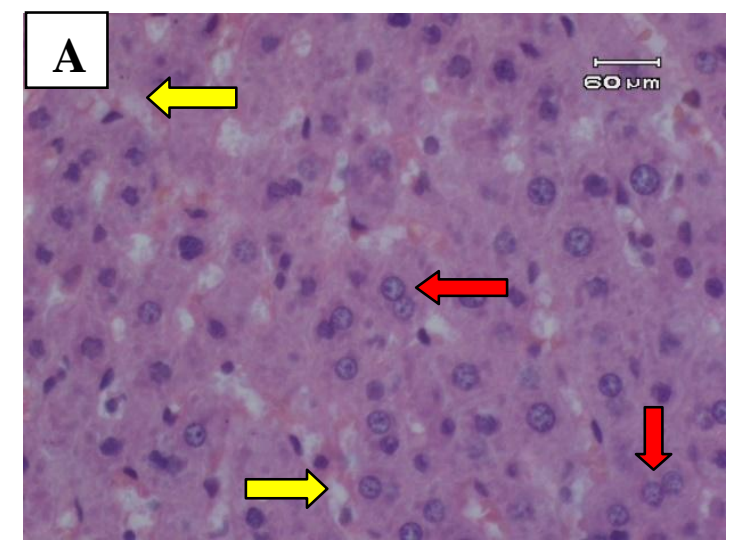

Gambar 4B. Gambaran mikroskopik hati tikus kelompok D (perlakuan 3). Tampak adanya gambaran sel hati yang mengalami regenerasi (panah merah) dan masih ada perlemakan hati (panah kuning). Pembesaran 40x.

\section{BAHASAN}

Penelitian ini dilakukan untuk melihat gambaran histopatologik hati tikus wistar yang diinduksi monosodium glutamate dan diberikan sari air bawang daun dan efek terapi dari pemberian sari air bawang daun terhadap hati tikus wistar yang telah diinduksi monosodium glutamate.

Pada tikus wistar kelompok kontrol negatif/A (Gambar 6 \& 7 ) ditemukan gambaran morfologi hati normal. Perbedaan yang jelas terlihat antara hati tikus wistar kelompok kontrol negatif (kelompok A) dan kelompok yang diberi monosodium glutamate selama 14 hari dan diterminasi pada hari ke-15 (kelompok B/perlakuan 1). Pada kelompok B (Gambar 9) tampak adanya sel-sel radang. Sel-sel radang yang terlihat diduga karena adanya cedera sel hati yang menyebabkan influks sel radang akut atau kronis ke hati. Serangan terhadap sel hati hidup yang mengekspresikan antigen oleh sel $\mathrm{T}$ yang telah tersensitisasi merupakan penyebab umum kerusakan hati. ${ }^{13}$

Pada kelompok B (Gambar 8) juga ditemukan perlemakan hati (steatosis) yaitu akumulasi lemak dalam sel hati. Stetatosis secara umum disebabkan oleh toksin, malnutrisi protein, diabetes mellitus (DM), obesitas dan anoksia. Penyebab terbanyak perlemakan hati ialah karena alkohol dan non alkohol. Penyebab non alkohol terbanyak ialah DM dan obesitas. Pada penelitian ini perlemakan hati diduga disebabkan toksin akibat pemberian monosodium glutamate (MSG). Asam lemak bebas dari jaringan adiposa atau makanan yang dikonsumsi normalnya bertransportasi/berpindah ke sel hati. Di dalam hati asam lemak bebas diesterifikasi menjadi trigliserida, diubah menjadi kolesterol atau fosfolipid, atau dioksidasi menjadi badan keton. Sebagian asam lemak juga disintesis dari asetat. Pelepasan trigliserida dari sel hati membutuhkan interaksi dengan apoprotein untuk membentuk lipoprotein, sehingga dapat melintasi sirkulasi. Akumulasi trigliserida yang berlebihan di hati dapat menyebabkan kerusakan pada salah satu urutan masuknya asam lemak bebas sampai pengeluaran lipoprotein. Kerusakan-kerusakan tersebut diinduksi oleh hepatotoksin (MSG) yang mengubah fungsi mitokondria dan mikrosom. Salah satu fungsi mitokondria yaitu sebagai organ respirasi sel. Oleh karena itu terganggunya fungsi mitokondria ini diduga menyebabkan anoksia sel, sehingga dapat menghambat oksidasi asam lemak. Dengan dihambatnya oksidasi, maka asam lemak berakumulasi di dalam hati dan menyebabkan perlemakan hati. Selain itu hepatotoksin dapat menurunkan sintesis apoprotein dan menimbulkan perlemakan hati. $^{12}$

Eritrosit di sinusoid seperti yang terlihat pada kelompok B penelitian ini merupakan tanda terjadinya inflamasi akut. Inflamasi akut diawali dengan vasodilatasi arteriol yang mengakibatkan peningkatan aliran darah dan penyumbatan lokal, selanjutnya mikrovaskulator menjadi lebih permeabel sehingga cairan yang kaya protein masuk ke dalam jaringan ekstravaskular. Hal ini menyebabkan sel darah merah menjadi lebih terkonsentrasi sehingga meningkatkan viskositas darah dan memperlambat sirkulasi. Secara mikroskopik akan tampak sejumlah pembuluh darah kecil yang dipadati oleh eritrosit. ${ }^{13}$

Saat sel hati mengalami cedera, maka sel hati yang berada pada fase $\left(\mathrm{G}_{0}\right)$ di luar siklus sel akan masuk ke fase $G_{1}$ dalam 
siklus sel dan dengan cepat mengalami mitosis (pembelahan) secara fisiologis sehingga sel hati beregenerasi. Respon perbaikan secara fisiologis hati pada tikus terjadi dalam waktu 5-7 hari. ${ }^{14}$ Dalam proses regenerasi sel hati faktor-faktor yang mempengaruhi, diantaranya faktor pertumbuhan seperti hepatocyte growth factor (HGF), interleukin-6 (IL-6), dan tumor necrosis factor- $\alpha$ (TNF- $\alpha)$. Regenerasi sel hati secara fisologis mulai terlihat pada kelompok C/perlakuan 2 (Gambar 10 \& 11), yaitu tikus yang diberi monosodium glutamate selama 14 hari kemudian dihentikan pemberian selama 5 hari dan diterminasi pada hari ke-20 (lihat Gambar 10 \& 11). Hal ini juga sesuai dengan penelitian oleh Andreas, dkk $(2015)^{1}$ yang menyatakan bahwa terjadi regenerasi hati setelah 14 hari penghentian panjanan MSG berlebihan. Pada kelompok ini juga tampak masih ada sedikit sel radang dan perlemakan hati (steatosis).

Kelompok tikus yang diberi sari air bawang daun selama 5 hari setelah pemberian monosodium glutamate selama 14 dan diterminasi pada hari ke-20 (kelompok D/perlakuan 3), menunjukkan regenerasi sel yang banyak dan sel hati sudah mulai kembali normal (Gambar 12 \& 13). Tanda-tanda regenerasi/perbaikan selsel hati pada kelompok ini tampak lebih banyak dibandingkan dengan yang terlihat pada tikus yang tidak diberi sari air bawang daun (kelompok C/perlakuan 2). Hal ini disebabkan oleh sifat dari sari air bawang daun sebagai antioksidan, anti-peradangan, anti-alergi, yang memberi efek sebagai hepatoprotektif. Sama halnya dengan pernyataan Sadikin, dkk $(2003)^{8}$ dalam penelitiannya menyatakan bahwa sari air bawang daun bersifat hepatoprotektif dan sifat ini disebabkan oleh kemampuan bawang daun mencegah sifat oksidan dari agen hepatotoksik dari monosodium glutamate (MSG).

Gambaran histopatologik yang berbeda antar kelompok hewan uji pada penelitian ini menunjukkan adanya pengaruh pemberian sari air bawang daun dalam mencegah kerusakan sel-sel hati karena cedera akibat pemberian monosodium glutamate yang berlebihan. Pada penelitian ini perbaikan jaringan hati belum terlihat pada seluruh populasi sel, sebab masih terlihat adanya perlemakan hati terutama pada kelompok tikus yang tidak diberikan sari air bawang daun. Jadi, kelompok tikus yang tidak diberikan sari air bawang daun membutuhkan waktu yang lebih lama untuk mengalami regenerasi sel hati.

Keterbatasan dari penelitian ini ialah kurangnya referensi yang cukup mengenai farmakokinetik dan farmakodinamik sari air bawang daun. Demikian juga dengan jumlah sel regenerasi, peradangan dan perlemakan sel tidak diukur secara kuantitatif, serta tidak dilakukannya evaluasi kesehatan tikus wistar yang digunakan dalam penelitian sehingga faktor-faktor yang dapat memengaruhi tingkat regenerasi sel hati pada tikus tidak dapat diperhitungkan. Hasil penelitian ini diharapkan dapat menambah informasi dan pengetahuan mengenai efek positif sari air bawang daun terhadap kesehatan terutama kesehatan organ hati dan dapat dikembangkan penelitian-penelitian yang berhubungan dengan tanaman bawang daun.

\section{SIMPULAN}

Dari hasil penelitian dapat disimpulkan bahwa penggunaan sari air bawang daun (Allium fistulosum L) dapat membantu (mempercepat) regenerasi sel hati akibat cedera yang disebabkan oleh monosodium glutamate.

\section{SARAN}

1. Perlu pertambahan jangka waktu dan variasi dosis sari air bawang daun.

2. Perlu dilakukan perhitungan secara kuantitatif jumlah sel regenerasi, sel radang dan perlemakan sel hati.

3. Perlu dilakukannya evaluasi kesehatan tikus wistar yang akan digunakan dalam penelitian.

\section{DAFTAR PUSTAKA}

1. Andreas $H$, Trianto $H$, Ilmiawan $M$. Gambaran Histologi Regenerasi Hati 
Pasca Penghentian Pajanan

Monosodium Glutamat pada Tikus

Wistar. Jurnal Fakultas Kedokteran

Universitas Tanjungpura.

2015;3(1):30.

2. Astuti NW. Studi tentang pemakaian monosodium glutamat (msg) beserta faktor-faktor yang berhubungan pada pedagang bakso di sekitar kampus undip tembalang [dissertation]. Diponegoro University; 2003.

3. Ardyanto TD. MSG dan kesehatan: sejarah, efek dan kontroversinya. INOVASI. 2004;1(XVI):52-6.

4. Insawang T, Selmi C, Cha'on U, Pethlert S, et al. Monosodium Glutamate (MSG) intake is Associated with the Prevalence of Metabolic Syndrome in a rural Thai population. Nutrition \& Metabolism. 2012 9(1):1-6.

5. He K, Du S, Xun P, Sharma S, Wang H, Zhai F, et al. Consumption of Monosodium Glutamate in Relation to Incidence of Overweight in Chinese Adults: China Health and Nutrition Survey. The Amirican Journal of Clinical Nutrition. 2011;93(6):1328-36.

6. Sherwood L. Sistem pencernaan. Fisiologi Manusia: dari sel ke sistem. Yesdelita N, editor. 6th ed. Jakarta: EGC; 2011.p.647.

7. Eweka AO, Igbigbi PS, Ucheya RE. Histochemical studies of the effects of monosodium glutamate on the liver of adult Wistar rats. Annals of medical and health sciences research. 2011;1(1):21-30.
8. Sadikin M, A Jusman SW, Harahap IP. Sifat Antioksidan dari Bawang Daun (Allium fistulosum L.) dan Perlindungan Terhadap Hati dari Keracunan CC14. Jurnal Bahan Alam Indonesia. 2003;2(4).

9. Siregar TM, Eveline E, Jaya FA. Kajian Aktivitas dan Stabilitas Antioksidan Ekstrak Kasar Bawang Daun (Allium fistulosum L.). InProsiding Seminar Nasional Sains Dan Teknologi Fakultas Teknik 2015 (Vol. 1, No. 1).

10.Aoyama S, Yamamoto Y. Antioxidant activity and flavonoid content of Welsh onion (Allium fistulosum) and the effect of thermal treatment. Food Science and Technology Research. 2007;13(1):67-72.

11.Guan YS, He Q. Plants consumption and liver health. Evidence-Based Complementary and Alternative Medicine. 2015 Jun 28;2015.

12. Contran RS, Kumar V, Collins T. Cellular pathology II: adaptations, intracellular accumulation, and cell aging. In : Robbins Pathologic Basic of Disease. 6th Edition.1999. p39-40.

13.Kumar V, Cotran RS, Robbins RL. Hati dan saluran empedu. Dalam : Hartanto H, Darmaniah N, Wulandari N, editor. Buku Ajar Patologi Robbins. Ed 7. EGC; 2007.p.664-90.

14.Guyton AC, Hall JE. Hati sebagai suatu organ. Alih bahasa : Rachman LY, Hartanto H, Novrianti A, Wulandari N. Buku Ajar Fisiologi Kedokteran. Ed.11, Jakarta;ECG;2007.p.902-07. 